\title{
FUMARIA JUDAICA SUBSP.INSIGNIS (PUGSLEY) LIDÉN (PAPAVERACEAE): A NEW FLORISTIC RECORD IN THE FLORA OF BOSNIA AND HERZEGOVINA AND NEW DISTRIBUTION DATA FOR THE TERRITORY OF CROATIA
}

\author{
Semir Maslo \\ Primary School, Lundåkerskolan, Södra Storgatan 45, 33233 Gislaved Sweden \\ (e-mailsemmas@edu.gislaved.se)
}

Maslo, S.: Fumaria judaica subsp. insignis (Pugsley) Lidén (Papaveraceae): a new floristic record in the flora of Bosnia and Herzegovina and new distribution data for the territory of Croatia. Nat. Croat., Vol. 29, No. 2, 307-311, 2020, Zagreb.

F. judaica subsp. insignis is a rare taxon in Europe. So far, this taxon has been reported only in Croatia, from a few localities along the Eastern Adriatic coast. F. judaica subsp. insignis is now reported for the first time for the flora of Bosnia and Herzegovina, and its distribution is extended to three new localities in Dalmatia.

Key words: Dalmatia, distribution, flora, Fumaria, Herzegovina, new taxon

Maslo, S.: Fumaria judaica subsp. insignis (Pugsley) Lidén (Papaveraceae): novi floristički nalaz u flori Bosne i Hercegovine i novi podaci o rasprostranjenosti na području Hrvatske. Nat. Croat., Vol. 29, No. 2, 307-311, 2020, Zagreb.

F. judaica subsp. insignis rijetka je svojta u Europi. Do sada je zabilježena samo u Hrvatskoj, na nekoliko lokaliteta uz obalu istočnog Jadrana. F. judaica subsp. insignis se ovdje prvi put navodi za floru Bosne i Hercegovine, a rasprostranjenost taksona se proširuje na tri nova lokaliteta u Dalmaciji.

Ključne riječi: Dalmacija, rasprostranjenost, flora, Fumaria, Hercegovina, nova svojta

\section{INTRODUCTION}

The genus Fumaria comprises approximately 60 predominantly Mediterranean species, some extending into central Europe, and others further west. Some may be found in India and a few in the mountains of East Africa (Murphy, 2009). Most accounts of Fumaria place great emphasis on the need for fully developed flowers and ripe, dry fruits for identification. The genus is divided into two sections, Capreolatae and Fumaria (LIDÉN, 1986).

In the flora of Bosnia and Herzegovina, 11 taxa of the genus Fumaria have been recorded (Fumaria capreolata L., F. densiflora DC., F. flabellata Gasp., F. gaillardotii Boiss., F. kralikii Jord., F. officinalis L. subsp. officinalis, F. officinalis subsp. wirtgenii (W. D. J. Koch) Arcang., F. parviflora Lam., F. petteri Rchb. subsp. petteri, F. rostellata Knaf and F. vaillantii Loisel.) (Beck von Mannagetta, 1916; Malý, 1927; Trinajstić, 1973; Maslo, 2015). 
Fumaria judaica Boiss. belongs to east Mediterranean floral element and its native distribution range is along the coast of the Eastern Mediterranean from Palestine to the Adriatic Sea, and to Egypt and Libya. It grows on walls, stony places, roadsides, but also penetrates into the garrigue. F. judaica belongs to the section Capreolatae (LiDÉN, 1986). According to LidÉn $(1986,2011)$ F. judaica Boiss. is divided into three subspecies: F. judaica Boiss. subsp. judaica, F. judaica subsp. amarysia (Boiss. \& Heldr.) Lidén and F. judaica subsp. insignis (Pugsley) Lidén. Focusing on these three subspecies, only F. judaica subsp. judaica has any very wide distribution in the Eastern Mediterranean. On the other hand, F. judaica subsp. amarysia is prevalent only in the territory of Greece, while F. judaica subsp. insignis is indicated only for the territory of Croatia.

So far, F. judaica subsp. insignis has not been recorded in the territory of Bosnia and Herzegovina. It was recorded in Croatia mostly on the Dalmatian islands of Dugi otok, Lastovo, the Palagruža archipelago and Vis (NiкоLIć, 2013), and has more recently been also reported from the Krka National Park (Sedlar et al., 2010) and from the Kvarner islands of Cres and Lošinj (FISCHER, 2015).

\section{MATERIAL AND METHODS}

During fieldwork conducted in Split (Dalmatia) and Počitelj (Herzegovina) in April 2018 and April 2019, several specimens of F. judaica subsp. insignis were collected. The specimens were identified according to Lidén (1986) and deposited in the Herbarium of the National Museum of Bosnia and Herzegovina (SARA 51998; 60018). Digital photographs and GPS coordinates were taken in the field. Plant taxonomy and nomenclature followed the Euro-Med checklist (Euro+Med 2006). The distribution of the taxon in Bosnia and Herzegovina and Croatia is shown on the map using standard $10 \times 10$ $\mathrm{km}$ UTM grid. Localities gathered from the literature are indicated in black on the map, while new data are indicated in red (Fig. 1).

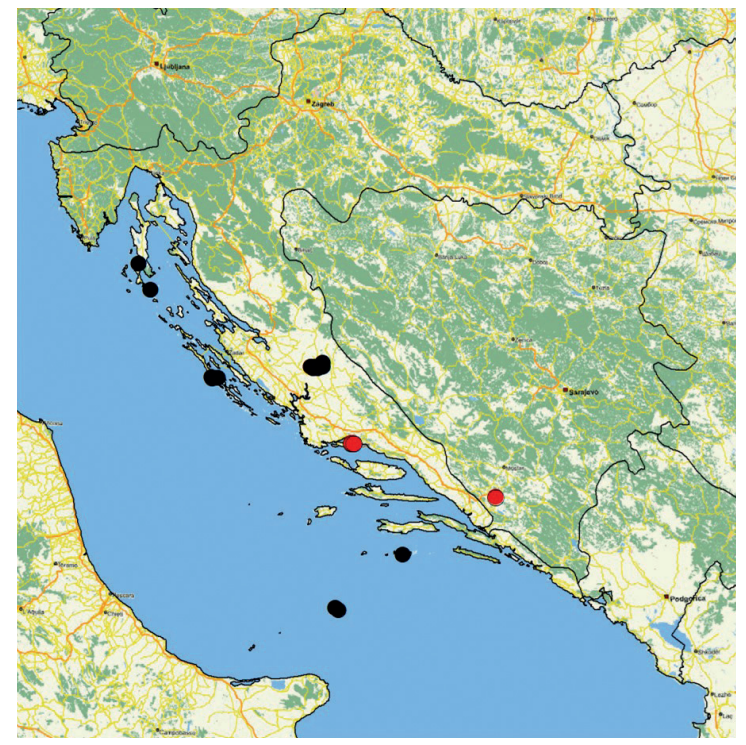

Fig. 1. Distribution of Fumaria judaica subsp. insignis in Bosnia and Herzegovina and Croatia (indication of localities: red circle - new chorological data; black circle - old literature data). 


\section{RESULTS AND DISCUSSION}

In April 2019, four Fumaria judaica subsp. insignis plants were found in southern Herzegovina, in the old town of Počitelj, near Ćapljina. Occurrence of this taxon has not been previously reported from Bosnia and Herzegovina. Likewise, no herbarium voucher of this taxon originating from Bosnia and Herzegovina was found in the Herbarium of the National Museum of Bosnia and Herzegovina during this study. The taxon was observed on April 16, 2019, on old walls at the entrance to the old town of Počitelj (43 $08^{\circ} 06^{\prime \prime} \mathrm{N}$; $17^{\circ} 43^{\prime} 50^{\prime \prime}$ E, $16 \mathrm{~m}$ a.s.1) (Fig. 2). Here, F. judaica subsp. insignis grows with characteristic wall-dwelling plants of the class Parietarietea judaicae Oberd. 1977 (BRullo \& Guarino, 1998), such as Arenaria leptoclados (Rchb.) Guss., Asplenium ceterach L. subsp. ceterach, Asplenium ruta-muraria L., Asplenium trichomanes subsp. quadrivalens D. E. Mey., Campanula erinus L., Cymbalaria muralis P.Gaertn., B. Mey. \& Scherb. subsp. muralis, Parietaria judaica L., Umbilicus horizontalis (Guss.) DC. and Veronica cymbalaria Bodard.

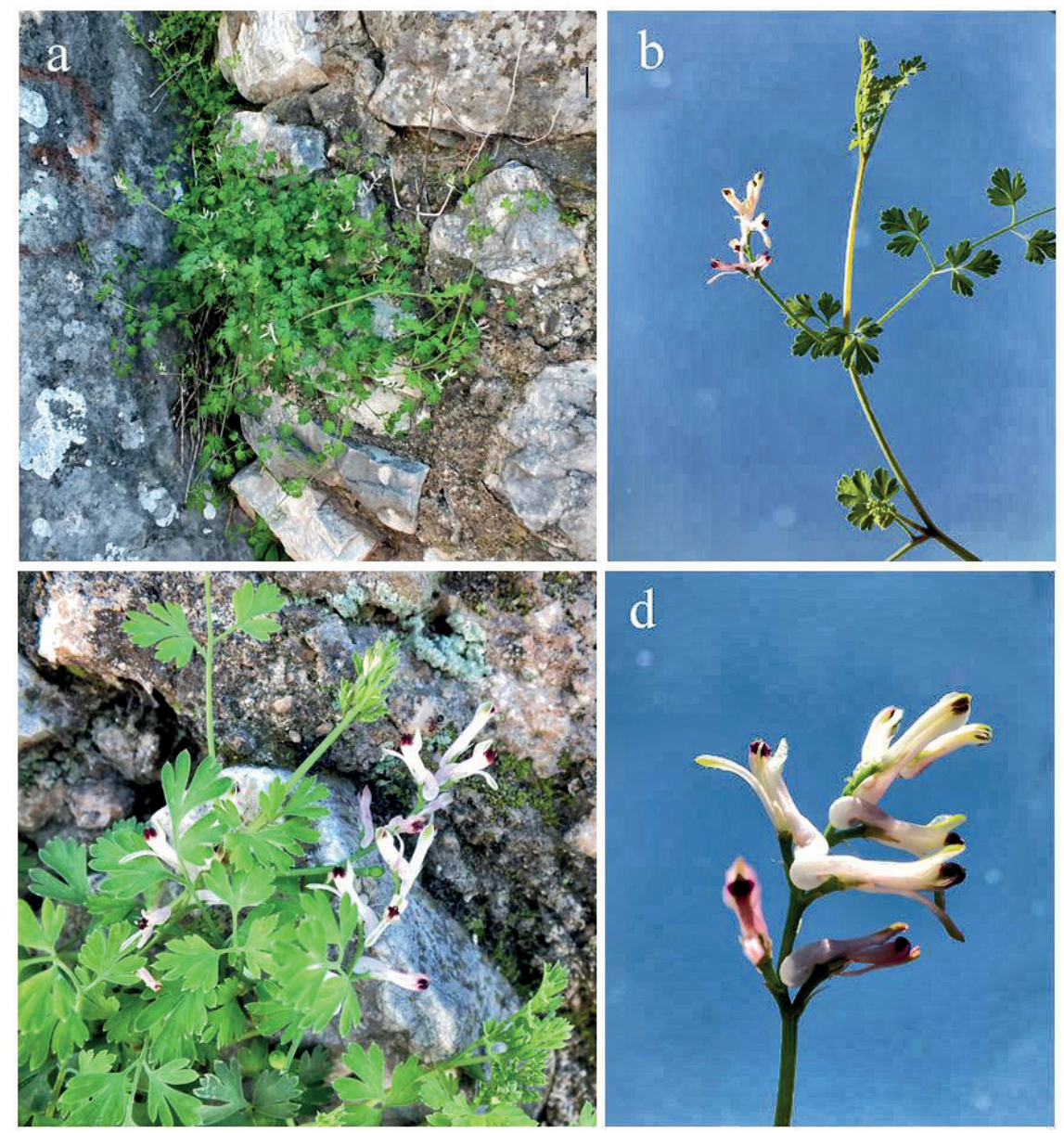

Fig. 2. Fumaria judaica subsp. insignis on the damp shaded walls in Počitelj, Herzegovina; a. habitat, b. whole plant, c, d. inflorescence (Photo by S. Maslo, April 16, 2019). 
Recent chorological data were gathered from Dalmatia (South Croatia), all within the city of Split, on Marjan Peninsula, on April 06 2018. The first locality was at Sustipan $\left(43^{\circ} 30^{\prime} 05^{\prime \prime} \mathrm{N}, 16^{\circ} 25^{\prime} 36^{\prime \prime} \mathrm{E}, 7 \mathrm{~m}\right.$ a.s.l), where five specimens were recorded on damp shaded walls and on surrounding rocks together with Allium neapolitanum Cirillo, Anisantha madritensis (L.) Nevski, Mercurialis annua L., Parietaria judaica L., Stellaria media (L.) Cirillo, Veronica cymbalaria Bodard, etc. (Fig. 3). The second locality was at Meje $\left(43^{\circ} 30^{\prime} 19^{\prime \prime} \mathrm{N}\right.$, $16^{\circ} 24^{\prime} 28^{\prime \prime} \mathrm{E}, 16 \mathrm{~m}$ a.s.l.), where two specimens were recorded on the old stone walls along the Ivan Meštrović Promenade, across from the Villa Dalmacija facilities, together with Anisantha madritensis (L.) Nevski, Fumaria gaillardotii Boiss., Mercurialis annua L., Parietaria judaica L., Umbilicus horizontalis (Guss.) DC., Veronica cymbalaria Bodard, etc. The third

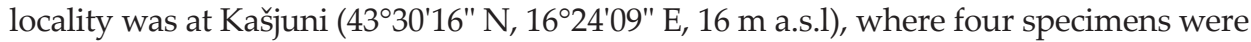
recorded on slopes of waste and soil piles near Kašjuni Bay, together with Fumaria bastardii Boreau, F. capreolata L., F. officinalis L. subsp. officinalis, Mercurialis annua L., Rapistrum rugosum (L.) All., Stellaria media (L.) Cirillo etc.

All specimens collected from Herzegovina as well as those from Split have all the characteristics of the subspecies F. judaica subsp. insignis, cited by Lidén (1986), which confirms that this taxon is present not only in Croatia, but also in Bosnia and Herzegovina. According to Trinajstić (1973) and Lidén (2011), F. judaica subsp. judaica is not present in the flora of Croatia. Fischer (2015), on the other hand, states the presence of this taxon on the two Kvarner islands.

\section{CONCLUSION}

The newly found sites with F. judaica subsp. insignis in Dalmatia are an important finding confirming the occurrence of this taxon in Dalmatia as well as first known site of this taxon for Bosnia and Herzegovina. It is very likely that F. judaica subsp. insignis is more widespread in both the coastal region of Croatia and southern Herzegovina. Given all the difficulties in determining the taxa of this genus, there is a high likelihood of confusion with other species. Further field researches as well as revision of the herbarium material are absolutely necessary.

Considering the low number of individuals and small extent of occurrence, F. judaica subsp. insignis should be treated as an insufficiently known taxon in the flora of Bosnia and Herzegovina.

\section{ACKNOWLEDGEMENTS}

The author would like to thank Magnus Lidén from Uppsala University, Sweden for assisting in the identification of this taxon, and Toni Nikolić from the University of Zagreb, Croatia for mapping the distribution of the taxon. Thanks are also due to Lanna Maslo (Malmö University, Sweden) for improving the English language of this paper.

Received February 11, 2020

\section{REFERENCES}

Beck von Mannagetta, G., 1916: Flora Bosne, Hercegovine i Novopazarskog Sandžaka, 2(7). Glasnik Zemaljskog muzeja u Bosni i Hercegovini 28(1), 41-167.

Brullo, S. \& GuARINo, R., 1998: Syntaxonomy of the Parietarietea judaicae class in Europe. Annali di Botanica 56(1), 109-146. 
EURO+MED, 2006: Euro+Med PlantBase - the information resource for Euro-Mediterranean plant diversity. http://ww2.bgbm.org/EuroPlusMed (Accesed January 2020).

Fischer, M. A., 2015: In Rottensteiner, W. K., Notizen zur „Flora von Istrien“, Teil, I. Joannea Botanik 12, 93-195.

Lidén, M., 1986: Synopsis of Fumarioideae (Papaveraceae) with a monograph of the Tribe Fumarieae. Opera Botanica 88, Lund, 1-133.

Lidén, M., 2011: Fumarioideae (excl. Hypecoum). In: Euro+Med Plantbase - the information resource for Euro-Mediterranean plant diversity.

MaLÝ, K., 1927: Mogorjelo 1918. eine floristische Skizze. Glasnik zemaljskog muzeja u Bosni i Hercegovini 39(2), 85-110.

Murphy, R. J., 2009: Fumitories of Britain and Ireland. Handbook Number 12. Botanical Society of the British Isles. London. pp 121.

Maslo, S., 2015: Fumaria gaillardotii Boiss. (Fumariaceae) - a New Species in the Flora of Bosnia and Herzegovina. Glasnik Zemaljskog muzeja Bosne i Hercegovine u Sarajevu. Prirodne nauke. Nova Serija 35, 55-59.

Nikolić, T. (ED.), 2013: Flora Croatica baza podataka / Flora Croatica Database. On-Line. URL: http://hirc. botanic.hr/fcd. Botanički zavod, Prirodoslovno-matematički fakultet, Sveučilište u Zagrebu (Accessed January 2020).

Pugsley, H. W., 1927: Further notes on the genera Fumaria and Rupicapnos. Botanical Journal of the Linnean Society 47(317), 427-469.

SEdlar, Z., HršAK, V. \& ŠEgOTA, V., 2010: New records of vascular plants for the new part of the Krka National Park. Natura Croatica 19(2), 433-443.

TrinajSTIĆ, I., 1973: Fumaria in Horvatić, S. \& TrinAjSTIć, I. Analitička flora Jugoslavije 1(2). Flora analytica Iugoslaviae. Šumarski fakultet - Sveučilišna naklada Liber, Zagreb, 408-420. 
